\title{
Propaganda in political strategy of the Czechoslovakian Communist Party during the first decade of the interwar Czechoslovak Republic
}

\author{
MiLAN OLEJNÍK \\ Centre of Social and Psychological Sciences SAS \\ Institute of Social Sciences, Košice
}

Abstract: Vital interest of the Communist Party of Czechoslovakia (CPC) in struggle to achieve political power was to make its program attractive to a broad masses of Czechoslovak population. The Marx-Leninism, which became an ideological base of CPC, presented itself as the only relevant ideology capable of establishing a "socially just" society. Revolution as a road of the Communist regime to impose its rule was presented as unavoidable, because it was in harmony with laws of social progress formulated by Friedrich Engels, Karl Marx and Vladimir I. Lenin. The essential role in spreading ideology of the Marx-Leninism, according to leadership of CPC had propaganda. Despite strictly formulated principles of the Marx-Leninist ideology, communist propaganda during the existence of Czechoslovak Republic morphed in dependence on changing political development. Vicissitudes of form and content of communist propaganda in monitored period are traced in submitted paper. An emphasis is given to, till now, unpublished archival documents, deposited in Slovak and Czech archives. Invaluable source offering insight to concrete workings of communist propaganda is a contemporary press, primarily periodicals Pravda Chudoby and Pravda, which represented ideological views of the Communist Party of Czechoslovakia. A relevant source of information are social democratic Robotnícke noviny, which monitored closely development of its main rival CPC. A literature dealing with various aspects with history of Czechoslovak Communist Party was used where it was suitable to complement events by a more general description.

Keywords: Communist Party of Czechoslovakia, interwar period, propaganda, journalism.

DOI: https://doi.org/10.24040/ahn.2021.24.02.61-78

The main objectives of propagandistic activities pursued by the Communist Party of Czechoslovakia

The inter-war Czechoslovak Republic (CSR) was a democracy composed of numerous political parties. Programs of individual political subjects were characterized by a broad scale of ideological values. Civic rights, social equality, religious beliefs and nationalistic ideology, constituted their ideological content. In comparison to the whole Czechoslovak political spectrum, the Communist Party of Czechoslovakia was a fundamentally different political organization. There were two characteristics, 
which placed CPC apart from rest of the Czechoslovak political scene. Firstly, CPC, unlike others subjects, negated existing political system in its entirety and declared unambiguous determination to destroy "capitalist" society. The goal of CPC was to establish a "dictature of proletariat". ${ }^{1}$ The way to impose communist regime would be achieved via violent uprising. The second specific feature of CPC, which was manifestly in breach with the Czechoslovak political system, was its adherence to transnational communist organization - the Communist International (CI), established in Moscow. Despite endeavours of conservative political parties to enforce prohibition of CPC, during existence of the Czechoslovak Republic this campaign did not succeeded.

In course of year 1920 a fraction within the Social Democratic Party was formed, which adhered to a radical political program formulated by the Communist International. Established was the Action Committee of the Marxist Left, which defined intention to form a political organization in line with ideological principles of the Communist International. In autumn1920 was published the first issue of periodical Pravda Chudoby (The Truth of Poverty), which became an official newspaper of the Marxist Left in Slovakia.

In Slovakia, dissention in the Social Democratic Party culminated during congress of the Marxist Left on 16 - 17 January 1921 in Lubochňa. Despite interference of state authorities, which terminated deliberations, delegates succeeded in accepting 21 conditions, whom every leftist political organization was obliged to adopt, if wanted to be admitted into the Communist International. ${ }^{2}$ Stipulations formulated by CI exactly delineated obligations of each member of CI. The main principle was unity and absolute subservience to decisions of CI. Strategy, tactic and ideological propaganda was required to be carried strictly in line with a course set-on by the Communist International. Leaders of communist parties must expel all members who have reservations to adopted political program. However, as future development shown, this stringent demand led to recurring conflicts within the Czechoslovak CPC. Even the Communist International itself was not immune to frictions among emerging fractions. By accepting 21 conditions (with exception of clause no. 17 demanding that accepted political organization must adopt name "the

\footnotetext{
1 „CPC, deducing principles of its policy from the Marxist concept of historical development...refuted any form of bourgeois society.” PLEVZA, Viliam et al. Prehl'ad dejín KSČ na Slovensku. Bratislava : Pravda, 1971, page (p.) 124.

${ }^{2}$ For more information in regard to early history of the Communist International see: BENKO, Juraj. K možnostiam, metódam a prostriedkom činnosti Kominterny v strednej Európe v prvých rokoch existencie (1919 - 1922): Na hranici legality a ilegality. In: ŠMIGEL', Michal a kol. Radikálny socializmus a komunizmus na Slovensku (1918 - 1989). Spoločnost' medzi demokraciou a totalitou. Banská Bystrica : Univerzita Mateja Bela, 2007, p. 11-25.
} 
Propaganda in political strategy of the Czechoslovakian Communist Party ...

Communist Party", because it was decided that this condition will be fulfilled at congress of all sections representing individual ethnic communities), split within the Social Democratic Party was irreversible.

In Czech part of the Republic, formation of the left fraction of the Social Democratic Party resulted also in a deep crisis. A crucial issue - joining the Communist International, was agreed upon during the XIII Congress of SDP in Prague. The chairman of the Marxist fraction, Bohumír Šmeral, declared that adherence to $\mathrm{CI}$ is the aim of the Party. Conservative leadership of SDP rejected leftist initiative and with assistance of police occupied SDP's headquarters, the Lidový Dům (Peoples House). Representatives of the radical fraction reacted by declaring the general strike. However, government with use of brachial power, suppressed the strike. On 15 December 1920 the strike was terminated.

Social democrats perceived the radical elements as the threat to very existence of SDP. The official periodical of the Social Democratic Party, the Robotnícke noviny (Workers News), accused the Left of insurrection against CSR and exhorted members of SDP to ignore strike. ${ }^{3}$ Robotnícke noviny with satisfaction reacted to unsuccessful attempt to rekindle strike in Slovak capital Bratislava. ${ }^{4}$

Despite ideological semblance - both parties were determined to struggle for wellbeing of workers and their ideology was based on works of Friedrich Engels and Karl Marx, their strategy and tactic were starkly different. Whereas social democrats refused use violence as a means to build a socially just society, communists perceived revolution as irreplaceable way to overthrow bourgeoisie. Therefore, to acceptation of 21 conditions by the Left, social democrats reacted with a stern criticism and become determined enemies of CPC. SDP characterized the Communist International as a sworn enemy of workers, as a tool of their enslavement and primary danger to democracy in Slovakia. ${ }^{5}$

\footnotetext{
3 "Comrades! Do not let yourself to get seduced to ill-considered acts, which could end only in same catastrophe as underwent proletariat in Hungary. Preserve everywhere peace and order. Do not believe communist lies. Keep working. This strike is pleasing only capitalists and it is only to detriment of working people." Robotnícke noviny. December 14, 1920, year XVIII, no. 255, p. 1. Pracujúcemu l'udu na Slovensku! (To working people in Slovakia!)

${ }^{4}$ Robotnícke noviny. December 17, 1920, year XVIII, no. 258, p. 1. Dohra „generálnej stávky“" (Epilogue of "general strike“.)

5 ,.... declaration of Third International confirms whole background of communist propaganda spreading among Slovak working people. It is not endeavour to increase life standards of working class and establish socialism. The goal is to break-up Slovak proletariat and enslave it... Declaration of III International reveal completely directions of this destructive institution, which proved to be helper of greatest reaction and violence." Robotnícke noviny. May 14, 1921, year XVIII, no. 106, p. 1. III. Internacionála pre zotročenie a podmanenie. (Third International for enslavement and subjugation.)
} 
The Communist Party of Czechoslovakia was established on $14-16$ May 1921, when delegates of the Founding Congress voted for acceptance of 21 conditions stipulated by CI. ${ }^{6}$ The Executive Committee of $\mathrm{CI}$ congratulated to the Czechoslovak Communist Party and expressed conviction that CPC became great reinforcement of European communist movement.

During early twenties, the main form of activities of CPC in Slovakia was organization of strikes, predominantly in industrial localities. These actions were focused on economic issues. Strikes organized by CPC, which frequently ended in violence causing injuries and even loss of lives, became severely criticized by all political parties, namely social democrats. They blamed communist activists and propagandists to be responsible for injuries and deaths of workers. ${ }^{7}$

A mile-stone in communist fight against regime was campaign of ruling coalition parties aimed at adoption of "The Law for Protection of the Republic", ${ }^{8}$ which was perceived by CPC as the most unacceptable political reactionary measure. The Communist Party organized a number of protests including violent obstruction in the Czechoslovak Parliament. However, CPC was not able to stop adoption of the above mentioned legal norm. ${ }^{9}$

In regard to ideological unity, discrepancies in CPC emerged already at the close of 1921. Representatives of "ultra" left fraction, led by Bohumil Jílek and Václav Bolen, argued that so called "offensive theory" is the only correct strategy to carry on revolution and must be pursued by the Communist Party. This strategy was contradicted by leader of CPC Bohumír Šmeral, who emphasized that only by gaining a majority of

\footnotetext{
6 "From all ends of the Republic gathered (...) representatives with goal to clean Party ranks from all bourgeois and capitalistic affixtures and to give it new lofty and beautiful name, name the Communist Party." Pravda chudoby. May 26, 1921, year II, no. 30, p. 1. Po zjazde. (After Congress.)

${ }^{7}$ Robotnícke noviny appealed to workers to ignore communist propagandists and expel them from their ranks: „We appeal to all workers, including honest communist idealists, to ignore seditious communist agitators in factories, to work with maximal diligence to expel them from our ranks. Communists are not only breaking-up union organizations, but are also initiating thoughtless strikes". Robotnícke noviny. December 7, 1920, year XVIII, no. 255, p. 1. Zločinné jednania komunistických štváčov. (Criminal acting of communist instigators.)

8 "The Law for Protection of the Republic" was adopted by the Czechoslovak Parliament on March 6, 1923.

${ }^{9}$ The regional periodical Slovenský východ wrote that voting was interrupted by communist deputies, who staged noisy protests and some of them were escorted from the Parliament by parliamentary guard. Slovenský východ (Slovak East). March 6, 1923, year XII, no. 54, p. 2. Komunistické škandály $\mathrm{v}$ československom parlamente. (Communist scandals in the Czechoslovak Parliament.)
} 
Propaganda in political strategy of the Czechoslovakian Communist Party ...

proletariat, revolution will succeed. ${ }^{10}$ B. Šmeral's strategy prevailed after Vladimír I. Lenin, the most influential personality in the Soviet Communist Party, supported his view and denounced proponents of the "offensive theory" as people who had no grasp of present situation in communist movement and do not understood that situation is not ready for uprising enacted only by a small group of revolutionaries.

Refusal of radical tendencies was presented during the First Ordinary Congress of the Communist Party, which commenced on February 2,1923 . In his opening speech Alois Muna, a chairman of the Executive Committee of CPC, declared determination of CPC to refuse provocations of ruling parties and pursue goal to establish a mass political organization. ${ }^{11}$

An immeasurable loss to the Communist International was sudden death of Vladimir I. Lenin. Grigory Zinoviev, a chairman of the Communist International, dispatched a short notice to all sections of CI, in which reported unexpected news. ${ }^{12} \mathrm{~V}$. I. Lenin was the most influential personality of communist movement. He was strong willed person, able to push his strategy and tactics against frequently occurring conflicting opinions. His death was a severe blow to unity of the Communist International.

A strategy for unification of international communist movement, enhancement of discipline, zero tolerance against dissenting fractions and

${ }^{10}$ According to B. Šmeral, „We (...) were working on creation of large party, without raising question: a large or a small party? Each of as felt that at home, where political life is strongly developed, where each party has broadly branched organizational apparatus, it is necessary a large party, if this party wants seriously think about conquering political power and does not want to be only an association of agitators." ŠMERAL, Bohumír. Výbor z díla, 1, 19021921. Praha : Svoboda, 1981, p. 483.

11 A. Muna declared: "Ruling classes of this state are afraid of mass communist party... Therefore, they want to provoke fight of which tactics and method they themselves would give direction... However, the Congress these intrigues will tear apart. We will not let ourselves to be seduced by provocations leading to non-intendent fights. Our line for immediate period is: To masses! United front! Unification of union organizations! Worker rule! This tactics will the Congress publicly elaborate in detail". Pravda chudoby. February 6, 1923, year IV, no. 11, p. 1. Prvý riadny zjazd komunistickej strany. (The First Ordinary Congress of the Communist Party.)

12 "Všetkým sekciám Komunistickej Internacionály. (To all sections of the Communist International.) 21. januára o 18 hod. 15 min. zomrel neočakávane Lenin. Pohreb bude v sobotu 26. januára. Komunistická Internacionála stratila svojho vodcu a učitel'a. Medzinárodný proletariát utrpel najväčšiu stratu od smrti Karola Marxa. Medzinárodný proletariát vie čo stratil $v$ Leninovi. Komunistická Internacionála a soviety zomknú svoje rady $k$ uskutočneniu toho čo nám Lenin odkázal." (On 21 January 18 h. 15 min. died unexpectedly Lenin. The burial will be on Saturday 26 January. The Communist International lost its leader and teacher. International proletariat knows what lost in Lenin. The Communist International and Soviets will unite their ranks to fulfil what Lenin bequeathed us.) Pravda chudoby. February 25, 1924, year V, no. 11, p. 1. Súdruh Lenin zomrel. (Comrade Lenin died.) 
above all willingness to follow the Soviet example in organization structure of communist parties, was adopted during the Fifth Congress of CI in June 1924. It was known as a program of "bolshevization". Despite proclamation that bolshevization is not a blind following of Soviet pattern, pressure was applied to ensure that principles on which the Soviet Communist Party was built, will be implied in each communist organization. This, however, was openly, or at least stealthily sabotaged by several European communist organizations, including the Communist Party of Czechoslovakia. The bulk of CPC members had their roots in the Social Democratic Party, in which ideological discipline was far less strongly enforced than in CPC. These people were mainly belonging to older generation and were less inclined agree with strict ideological imperatives enforced on them. Leaders of the Communist International were aware of this incongruity and difficulties which could occur in future, but were convinced that bolshevization was the only way to preserve ability of communist parties to be victorious in struggle against bourgeoisie. Consequently, the Fifth Congress of $\mathrm{CI}$ in its resolution emphasized necessity of bolshevization and insisted on upholding its main principles, such as close relation with masses, use all tactical steps to wage a resolute fight against all sectarian diversions. ${ }^{13}$

Instructions of the Communist International in regard to bolshevization became the main topic of deliberations during the Second Congress of CPC enacted on October 31,1924. At that time unity of CPC was weakened by emergency of fractions. Party was divided to two camps - the Left led by Josef Haken, which was unconditionally loyal to CI and to more independent group represented by Josef Bubník. Adherents of J. Haken had a slight majority in the Central Executive Committee and in resolution named "Agitation and propagation of Leninism", emphasized necessity to be aware that without "deep penetration of the Marxist-Leninism to consciousness of Party members there is impossible a real bolshevization of CPC." Delegates also decided to establish an agitation and propagation department. ${ }^{14}$

Differing arguments, which emerged during the Second Congress of $\mathrm{CPC}$, revealed a deep cleavage between both fractions in regard to evaluation of political situation and strategy, which CPC must take. B. Šmeral refused to take sides and argued that he has no intention to worsen situation in the Party. In addition, he expressed doubts that there

\footnotetext{
13 Štátny archív Košice (State Archive Košice - SA Košice), fond (f.) Košická župa (Košice County - KC), box (b.), number (no.) 14.112. Rezoluce V. Kongresu Komunistické Internacionály. (The Resolution of the Fifth Congress of the Communist International)

14 BRADÁČ, Zdeněk. Boj za bolševizaci KSČ v období dočasné stabilizace kapitalizmu 19241926. Praha : Státní nakladatelství politické literatury, 1955, p. 194.
} 
Propaganda in political strategy of the Czechoslovakian Communist Party ...

are serious threats to unity of CPC. ${ }^{15}$ However, J. Haken, a representative of radicals, criticized denial of existence of the right fraction - according to him this was inimical to unity of the Party. There was also a radical change in approach toward policy of the United Front. Conciliatory strategy toward non-communist parties was refused as opportunistic and condemned was any activity leading to coalition with the Social Democratic Party. 16

\section{Implementation of the factory cells to organizational structure of the Communist Party and its consequences}

A radically new approach to build-up CPC structure was creation of networks of cells in industrial facilities. The initial idea was conceived by V. I. Lenin, who expressed necessity of cell implementation arguing, that "...the main power of movement is in organization of workers in large factories (...) where predominant segment of the whole working class is situated, predominant not only by its numbers, but even more by its influence, forwardness and fighting power."17

According report dispatched to security authorities in Slovakia by the Ministry with full Powers for Administration of Slovakia (MPS) on May 24,1924 , a session of the Executive Committee (EC) of CPC was enacted. Session valuated significance of cells in factories, arguing that cell is primarily an "operational division, which will be prepared to carry fight against capitalist class." Cells were valued as highly suitable instruments influencing non-communist workers to become members of CPC, or at least become sympathizers of communist movement. Therefore, in judgement of EC CPC, it was necessary to commence build-up of cells at factories, because "without efficient network of cells victory of proletarian revolution would be hardly realistic". 18

Important in regard to restructuring of CPC was a resolution, which was unanimously approved during the Fifth Congress of the Communist International. The resolution stated that "Organizational base of a communist party must be anchored in worker masses themselves, in factories, in working process. Only build-up of party on the base of factory cells enable constant and tight contact and connection with

\footnotetext{
15 Pravda chudoby. November 7, 1924, year V, no. 134, p. 1. II. riadny zjazd KSČ. (Second Ordinary Congress of CPC.)

${ }^{16}$ BRADÁČ, Zdeněk. Boj za bolševizaci KSČ, p. 156.

17 JÍŠA, Václav. K organizační výstavbě KSČ v letech 1921 - 1925. In VOLKOVÁ, Květoslava (ed.). V bojovém svazku, Komunistická strana Československa a Komunistická Internacionála (1919 - 1943). Praha : Svoboda, 1988, p. 85.

${ }^{18}$ SA Košice, f. KC, b. 44, no. 6695/24. adm. rev. Nové organizačné metódy komunistickej strany. (New organizational methods of the Communist Party.)
} 
masses. This way party can reinforce its influence (...) and organize fight for power."19

With aim to precisely define all obligations related to propagation activities of cells, the Agitation and Propagation Department of CPC published a brochure defining individual steps, which must be realized by cells. In an introductory part it emphasized that for effective propagation is essential "deep knowledge of Leninism" and constant political agitation. It asserted that importance of press must be upheld by constant care to maintained flow of periodicals, posters and appeals to participate on activities organized by the Party. In area of agitation, members of cells had a decisive role but no less important, according CPC, were agitation activities by members of cells among agricultural workers, women and youth people. It was also necessary to intensify propagation of the Soviet Union. ${ }^{20}$

In April 1925 CPC issued a circular letter, which defined obligations of cells in sphere of propaganda. Repeated was requirement addressed to all members to read periodicals published by CPC. ${ }^{21}$ In addition, a number of shortcomings was notified, namely slow process of creation of factory cells, reluctance of the members of the Communist Party to join industrial cell organizations, sparse propaganda in country side and weak anti-clerical agitation. Criticized were also irregular connections of local organizations with the Party Headquarters, which caused insufficient knowledge of headquarters about general state of situation in local CPC organizations. ${ }^{22}$ Persistent reluctance on part of some members of street cells to join factory organizations was criticized by the Central Committee of CPS in a circular dated October 7, 1926. CC CPC criticizes that street cells were incapable to cope with work load and were failing to "follow example of Russian comrades". ${ }^{23}$

Difficulties besetting transfer from street cells to factory organizations were also frequently occurring during following years. In a circular letters published by central authorities of $\mathrm{CPC}$, numerous qualms were

\footnotetext{
${ }_{19}$ Pravda chudoby. August 17, 1924, year V, no. 99, p. 1. Uznesenie V. svetového zjazdu Komunistickej Internacionály. (Resolution of the Fifth World Congress of Communist International.)

${ }^{20}$ SA Košice, f. Policajné riaditel'stvo Košice (Police Directory Košice - PD K), b. 8. KSČ. Agitačné - propagačné oddělení. Agitačně-propagační práce v buňce. (The Agitation-Propagation Department. Agitation and Propagation Works in cells.)

${ }^{21}$ SA Košice, f. KC, b. 77, no. 3576/1925 adm. rev. Nové organizačné metódy Komunistickej strany. (New organizational methods of the Communist Party.)

${ }^{22}$ SA Košice, PD, b. 5, no. 1739/prez.2. Komunistický propagační materiál. (Communist propagation material.)

${ }^{23}$ SA Košice, f. KC, b. 144, no. 5643/926 adm. rev. Ústredný výbor Komunistickej stany ČSR o prestavbe uličných buniek. (Central Committee of the Czechoslovak Communist Party in regard to reconstruction of street cells.)
} 
Propaganda in political strategy of the Czechoslovakian Communist Party ...

raised. Among most frequent alleged drawbacks was failure of factory cells to become leaders of workers in industrial plants. Publishing of periodicals was criticized as insufficient; meetings were allegedly boring and haphazardly prepared, ideological education neglected and activities focused on gaining of new members were not successfully carried out. ${ }^{24}$

\section{Specifics of communist propaganda and agitation focused on various segments of society}

As one of the most important goals in the area of propaganda was for CPC to gain a foothold in the Czechoslovak Army. Leadership of CPC was convinced that successful propagation of communist ideology among young workers recruited to military service, is the vital precondition for usurpation of power by the Communist Party in CSR. However, these aspirations were closely monitored by the leadership of the Czechoslovak Army. In 1925 (more precise date is not given) the Ministry of National Defence published "The Activity of the Commintern in Czechoslovakia with a special regard to the Czechoslovak Army." The report was composed from sources gathered by the General Staff, covering time span 1921 - 1925. According to authors, "The main aim of publishing this report was point more closely to movement, which must be not ignored nor belittled." 25 An attention was given to communist propaganda and to threat that "The Communist Party in no way is abandoning its endeavors directed toward usurpation of all power in state, and is systematically working to reach stated goals. Unlike during beginning of twenties, when communist propaganda was in disarray, lately is well planned and is showing considerable results among workers and state employs. Slight success of CPC, in military so far, is due primarily to intensive care to prevent communist infiltration." 26 Allegedly, the main organization spreading propaganda in the Army, was the Union of the Communist Youth of Czechoslovakia (UCYC), established

\footnotetext{
${ }^{24}$ SA Košice, f. KC, b. 154, no. 514/27 adm. rev. Komunistická strana, rozvrh práce pre buňky v Bratislave. (The Communist Party, schedule of work for cells in Bratislava.) Also SA K, f. KC, b. 200, no. 6535/27 adm. rev. Komunistická strana - agitácia. (The communist Party - agitation.)

${ }^{25}$ Archív Ministerstva zahraničních věcí České republiky (Archive of the Foreign Ministry of the Czech Republic - AMFA ČR), II. section (s.), III. row (r.), b. 276. Z činnosti Kominterny v ČSR se zvláštním zřetelem k čs. armádě. Mimořádná správa, 1925. (Activity of the Commintern in Czechoslovakia with special regard to Czechoslovak Army. Extraordinary report.)

${ }^{26}$ AMFA CR, II. S., III. r., b. 276. Z činnosti Kominterny v ČSR se zvláštním zřetelem k čs. armádě. Mimořádná správa, 1925. (Activity of the Commintern in Czechoslovakia with special regard to Czechoslovak Army. Extraordinary report. Introduction.)
} 
on February 20,1921. The exclusive aim of UCYC, was to transform the Army into a power instrument of the Communist Party. According to communist agitators, military training was to be perceived positively, because acquired skills will be essential for victory of revolution. In conclusion, authors of the report asserted that "Submitted material, is sufficiently proving that communist movement is the movement seriously endangering security of our state... Therefore it has to be very thoroughly monitored, planned anti-state actions timely disclosed and all attempts of subversive nature ruthlessly suppress."27

An efficient tool in spreading anti-military propaganda were leaflets. Leaflets could be displayed either inside of military barracks, or at public places, conveying political declarations, appeals and anti-government slogans. Communists in military service were obliged to distribute leaflets among apolitical recruits. ${ }^{28}$

Also women were preferred targets of communist propaganda, which was focused to encourage their participation in the Communist Party ranks. An important segment of propaganda was focused upon high prices and low wages. The Secretariat of Women of CPC for Slovakia on December 8, 1924, informed that the Communist Party enacted a campaign against "economic and political terror". Agitation commissions, composed of female members of CPC, were instructed to organize distribution of periodicals ${ }^{29}$ and leaflets and induce apolitical women to join the Party. On November 21, 1925, the Secretariat dispatched to all executive commissions a guidance how to carry on agitation. Executive commissions were obliged to observe situation of women and gained information which could be utilized in struggle for better social security of women. An urgent appeal to members of CPC was expressed to secure support for periodical Proletárka, which allegedly was in catastrophic financial situation. ${ }^{30}$

\footnotetext{
${ }^{27}$ AMZV ČR, II. s., III. r., b. 276. Z činnosti Kominterny v ČSR se zvláštním zřetelem k čs. armádě. Mimořádná správa, 1925. (Activity of the Commintern in Czechoslovakia with special regard to Czechoslovak Army. Extraordinary report.)

${ }^{28}$ On March 13, 1926, MPS informed state authorities in Slovakia about intention of CPC to distribute a large amount of leaflets among soldiers on occasion of the Paris Commune. SA K, f. KC, b. 123, no. 2122/26 adm. rev. Akcia komunistov medzi vojskom a študentstvom. (An action of Communists among soldiers and students.)

${ }^{29}$ The periodical devoted to status of working women in Slovakia was Proletárka. Orgán Slovenských komunistických žien. (Proletarian woman. A Periodical of Slovak Communist Women.) ${ }^{30}$ SA Košice, f. PR K, b. 2, no.13 983/24 adm. pres. Komunistická strana - hnutie žien. (Communist Party - The Movement of Women.)
} 
Propaganda in political strategy of the Czechoslovakian Communist Party ...

Leaders of CPC decided that starting October first, 1925, periodical Pravda will be published as daily. ${ }^{31}$ In a leaflet dispatched to all cells and district headquarters of CPC in Slovakia, was emphasized significance of this change for propagation of communist ideology. However, at the same time, accentuated obligation of every communist to provide financial support. CPC declared, that it was necessary to improve a network of correspondents, secure distribution of Pravda to all cells and provide free copy to non-members of CPC. Designated member of every cell was responsible for colportage of Pravda. ${ }^{32}$ But, despite appeals, as a result of insufficient fulfilment of financial obligations, Pravda found itself in existential problems. On February 12,1926, redaction of periodical dispatched an urgent appeal to communist organizations in Slovakia to pay-off accrued arrears. ${ }^{33}$ Also, according to circular letter sent on July 1926 to all cells, also periodical Proletárka was allegedly in a grave financial crisis. Also in this case, cause of debt were lacking payments for distributed periodicals. ${ }^{34}$

With aim to increase attractiveness of communist press, namely among young members of the Party, the Central Secretariat of Young Workers issued instructions for correspondents, who were obliged to provide continuous flow of information about "class fight" in factories and villages. The task of periodicals and leaflets was to inform about situation with eye upon status of young workers. Correspondents should promptly report conflicts in factories. Again, an appeal was raised to distribute periodicals free of charge to "indifferent" workers. ${ }^{35}$ However, distribution of communist press was complicated by measures of state authorities. Beside frequent confiscations, hindrance to distribution of communist press was prohibition of selling periodicals published by CPC in tobacco stores and public places. ${ }^{36}$

\footnotetext{
31 The periodical Pravda commenced publishing on September 4, 1925 as successor of Pravda Chudoby, which ceased publishing on September 2, 1925.

${ }^{32}$ SA Košice, f. KC, b. 97, no. 10468/25 adm. rev. Komunistická strana - propaganda komunistickej tlače. (The Communist Party - propagation of communist press.)

33 „As a consequence of outstanding debts of cells and sections...we found ourselves in maximal financial crisis and we are not able to pay-off our debt to printing house, which threaten to terminate publishing of our periodical. And comrades! It is now your turn to prove that our periodical is your concern". SA K, f. KC, b. 120, no. 974/1926 adm. rev. Komunistická strana - propaganda tlače. (The Communist Party - propaganda of press.)

${ }^{34}$ SA Košice, f. KC, b. 174, no. 6657/1926 adm. rev. Komunistická strana - ženské hnutie. (Communist Party - the Movement of Women.)

${ }^{35}$ SA Košice, f. KC, b. 185, no. 3245/1927 adm. rev., May, 5, 1927. Komunistická strana v ČSR, pokyny pre robotníckych dopisovatel'ov. (The Communist Party in CSR, instructions for worker correspondents.)

${ }^{36}$ The Presidium of the Ministry of Finances on September 21, 1929 ordered to retailers of tobacco products and press to stop selling communist periodicals. SA Košice, f. PD, b. 10,
} 
The Communist Party of Czechoslovakia perceived itself as the only political subject build in harmony with scientific knowledge of social development. The Historic Materialism, the Dialectic Materialism and above all the Scientific Communism were pillars on which rested communist ideology. Consequently, knowledge of the Marx-Leninism was declared as the most relevant tool for formation of communist strategy and tactic. Hence, obligation to master thesis of the Marx-Leninism was imperative duty of each member of the CPC and became an integral part of communist propaganda. But, not all communists approached this commitment with pronouncedly positive attitude. Especially among older party members, predominantly former social democrats who were not used to strict requirement study the Marx-Leninist lore, this demand was frequently ignored.

V. I. Lenin, a leader of the Soviet Communist Party, whose thesis in regard to tactics and strategy of communist movement were accepted by the Communist International without objection, declared that knowledge of the Marx-Leninism by each communist is irreplaceable condition for victory of revolution. In the "The Resolution about Agitation and Propaganda of Leninism" (The Resolution), adopted during the Second Congress of CPC, is emphasized necessity to create a staff of trained propagandists, qualified to teach members of the Party the Marx-Leninism. In frame of CSR, establishment of educated trainers was perceived as essential namely in Slovakia, where a large segment of population were practicing Catholics, including members of CPC. The Communist Party of Czechoslovakia appealed to all organizations of CPC to "...raise conscious, focused and educated class fighters." ${ }^{37}$

CPC considered theory of the Marx-Leninism the essential part of propaganda, and organized in Slovakia so called the Party Schools (Bratislava, Košice, Vrútky), lasting $4-6$ weeks. In accordance with teaching program, courses were to be attended primarily by "best members of CPC" of age 18 - 35 years. ${ }^{38}$ With aim to elevate theoretical level of communist propaganda, CPC cells were to establish courses, focused upon explanation of CPC program "in plain and intelligible language", which will be comprehensible to all members of cells. Each cell was instructed to select one person, qualified to teach courses. With unwarranted

no. 50.126 /29 prez. Komunistická tlač, predaj v trafikách a nádražiach. (Communist press, sale at tobacco shops and railway stations.)

37 1924, 31 October - 4 November, Rezoluce o agitaci a propagaci leninismu, přijatá na II. Sjezdu Komunistické strany Československa. In Dokumenty moderní doby. Praha : Svoboda, 1978, p. 185.

${ }^{38}$ SA Košice, f. KC, b. 62, no. 57/925. adm. rev Komunistická strana na Slovensku - činnost'. (The Communist Parry in Slovakia - activity.) 
Propaganda in political strategy of the Czechoslovakian Communist Party ...

optimism, leaders of the Communist Party declared, that these courses will create "the whole army of competent people, able to spread communist ideology, especially in ranks of indifferent but with the Communist Party sympathetic workers." 39

CPC expected positive results also from campaign of self-education, consisting of individual and collective study of political literature. According to information gained by the Department of the Ministry of Interior in Bratislava, CPC organized self-educating campaigns in autumn months of 1927 with goal "to increase level of education of workers in issues of class fight." CPC recommended that attendants of self-education circles, who yet not absolved any form of schooling, should be introduced to the Marx-Leninism in its elementary form. ${ }^{40}$ The Department of the Ministry of Interior in Bratislava considered organization of education circles as the "threat to state security" and instructed authorities to terminate these activities. ${ }^{41}$

The Presidium of the Land Office (PLO) in Bratislava informed state authorities in Slovakia also about other forms of schools organized by the Communist Party of Czechoslovakia. Teaching classes were realized by individual types of CPC schools, among them schools for propagandists, the Party officials and CPC educators active in country side. ${ }^{42}$

A special type of educational institution, which should increase influence of the Communist International upon political development of communist parties, was the "International Lenin's School" in Moscow. To be accepted, candidates must be at least three years active in the Party leadership. Preference had not married workers. Examination board tested satisfactory knowledge of essential works of F. Engels, K. Marx, V. I. Lenin and J. V. Stalin. Good health was precondition for acceptation. Precondition for acceptation was also knowledge of German or Russian language. Successful candidates were Isolated from political situation in their home countries for several years, students became fully integrated into realities of political development in the Soviet

\footnotetext{
${ }^{39}$ SA Košice, f. KC, b. 119, no. 496/1926 adm. rev. Komunistická strana - zriadenie agitačných, propagačných kurzov. (The Communist Party - establishment of agitation, propagation courses.)

40 SA Košice, f. KC, b. 237, no. 9913/1927 adm. rev. Komunistická strana - Komunistická strana - seba-vzdelávacie krúžky. (The Communist Party - self-education circles.)

${ }^{41}$ SA Košice, f. KC, b. 237, no. 5749/1928 prez. Kurzy a školy poriadané komunistickou stranou. Seba-vzdelávacie krúžky KSČ. (Classes and schools organized by the Communist Party. Self-education circles of CPC.)

${ }^{42}$ SA Košice, affiliated branch (ab.) Rožňava, f. Rožňava County (RC), b. 19, no. 1102 prez. Školenie členstva. (Training of members.)
} 
Union. Hence, after return to their home countries, they served as reliable executors of CI policies. ${ }^{43}$

Young adherents to communist movement, in comparison to older generation, were characteristic by their deep adherence to radical leftist ideology. In January 1921 the Communist Union of Czechoslovak Youth - Komsomol, was established. Komsomol unified Czech, Slovak, German, Hungarian and Ukrainian sections of CPC. MPS in a letter issued on May 8, 1921, informed state authorities that "According received reports, organizations of communist youth are acting very aggressively... Their role is to inseminate communist propaganda among young people." ${ }^{4}$ However, legal status of Komsomol had short duration. On September 28, 1921, Komsomol was dissolved by the Ministry of Interior. Consequently, CPC must look for other ways to maintain existence of young communist organization. The Executive Committee of CPC, during session enacted on June 3,1923, came to conclusion that to preserve existence of organization of young people, it will be necessary to establish sections of youth as a constituent of the Communist Party establishment. This way young sections will be protected against persecution, because they will become an integral part of the Communist Party, which was a legal political organization. ${ }^{45}$ However, according to Antonín Zápotocký, a General Secretary of CPC, expectations that young communist will became a driving force in the Party, did not materialized. In his speech during the Session of the Communist Youth on November $3-4,1924$, he was surprisingly critical, accusing young communists of alleged indifference to activities of CPC. But, no less critical was he of contemptuous attitude toward young communist organizations exhibited by adult members of the Communist Party. In closing part of his speech he appealed to mobilize young people to fight against prejudices of adults. ${ }^{46}$

\footnotetext{
${ }^{43}$ SA Košice, f. KC, b. 209, no. 10792/27 prez. rev. Medzinárodná leninská škola v Moskve, inštrukcie k prijatiu. (International School of Lenin in Moscow - instruction for acceptation.)

${ }^{44}$ SA Košice, f. PD K, b. 2, no. 2990 adm. rev. Vstupovanie mládeže do spolkov. (Entry of young people to associations.)

45 TKADLEČKOVÁ, Herta. Miesto Komsomolu v slovenskom robotníckom hnutí. Bratislava : Smena, 1981, p. 37.

46 "...we must found out how is possible that in the Party as well as in movement of working young people exist such inexplicable indifference. Number of copies of communist periodicals were never before so low, colportage of literature never was so lackadaisical, activities never were so negligent, never so small was participation at our demonstrations... At the end yet several words in regard to relation of the Party toward to youth, which there are voiced many complains. In regard to many organizations it is justified criticism. These organizations are exhibiting a deep indifference toward young workers... But, it is also necessary on part of young workers initiatively fight against prejudices of adults." SA Košice, f. KC, b. 31, no. 539/24 adm. rev. Ríšska konferencia komunistickej mládeže. (Republic Conference of communist youth.)
} 
Propaganda in political strategy of the Czechoslovakian Communist Party ...

A significant sign of low discipline was negligence, which characterized reports of public meetings to the headquarters enacted by young communist organizations. This was perceived by the Central Secretariat of Youth (CSY) as unacceptable. On March 11, 1925, CSY instructed district secretariats to report all gatherings, speeches and sessions enacted in their localities.

Essentially important for insemination of communist propaganda in ranks of young workers were valued correspondents. Their duty was to provide a flow of information from factories and country side, inform about strikes and about any form of resistance against regime. ${ }^{47}$

With goal to enhance discipline and efficiency of the communist young movement, the Fifth Congress of the Youth Movement of CPC (April 3 - 5, 1926) adopted the Organizational Order of the Youth Movement of CPC, which in detail delineated structure, mission and ideological composition the communist youth organization. ${ }^{48}$ The Youth Movement of the Communist Party of Czechoslovakia was defined as an integral part of the Communist International of Youth (CIY). The program and regulations of the Youth Movement were to be enacted strictly in line with instructions and resolutions of CIY. In comparison to non-communist youth organizations, strict discipline was required. ${ }^{49}$

As an important segment of propaganda was to description of life in the Soviet Union. Obligation of communist agitators was to portray the Soviet Union as a harmonic and prosperous country, where young people, in contract to capitalistic states, were not target of exploitation. Adoration of life in the Soviet Russia was a significant part of communist propaganda. Besides accolades of alleged achieves of Soviet people, also celebrations of communist victory in the Soviet Union became obligatory. ${ }^{50}$

However, in summary valuation of situation, according to overviews elaborated by county secretariats, activities of communist organizations were beset by serious shortcomings. ${ }^{51}$ A lasting problem in the sphere of

\footnotetext{
${ }^{47}$ SA Košice, f. PD K, b. 2, no. 4091/925 adm. rev. Hlášení schůzí. (Report of meetings.)

48 Organisační řád hnutí mládeže Komunistické strany Československa. Karlín. Ústřední výbor mládeže KSČ, year 1926.

${ }^{49}$ Ibidem.

50 On July 12, 1927, The Central Secretariat of Youth issued to all local organizations of CPC a circular letter, in which informed about approaching tenth anniversary of communist revolution in the Soviet Union and instructed them to initiate preparations to celebrations. Campaign should be composed of history of "October struggle" with accent upon role of youth, emphasize accomplishments of Soviet economy and denounce threats against the Soviet Union by "imperialistic states". SA Košice, f. KC, b. 186, without number. Kampaň k desiatemu výročiu ruskej revolúcie. (Campaign in regard to tenth anniversary of the Russian Revolution.)

${ }^{51}$ In report from County Žilina is written, that "In Žilina County our movement is not satisfactory. Reason for it is high unemployment and worries to lose jobs... Also movement was built on old system and new was realized only on paper." Difficulties are reported also
} 
propaganda were difficulties affecting communist press. In a circular letter dispatched by headquarters CPC on March 11, 1925 is expressed an appeal to enhance quality of periodical press, because it was valued as essential tool of spreading propaganda. But, because central newspapers were allegedly not capable of satisfy all tasks of propaganda, it was necessary to build also a network of factory periodicals published by individual cells, which would focus agitation upon concrete situation in factories and become a "voice of workers". CPC advised, that periodical should be composed of a, editorial, which will summarize concrete situation at factory; b, of samples from correspondence of workers; c, appeals to participate on demonstrations, meeting etc. ${ }^{52}$

Endeavor to enhance knowledge of the Marx-Leninism was also focused on young CPC members. V. I. Lenin unequivocally expressed significance to educate young people as irreplaceable condition for creation of communist society: "Only if we from the ground remake educational process, organization and upbringing of youth, we will be able, to achieve build-up of society, which will in nothing resemble old-one, that it will be a communist society." 53

Despite pressure to implement principles of organization structure according to Soviet example, resistance by a large segment of CPC membership persisted and resulted in a chronic crisis, which threatened a very existence of the Party. ${ }^{54}$ According communist historian Fridrikh I. Firsov, during the second half of 1920 the Communist Party of Czechoslovakia was losing its "revolutionary zeal" and became a battlefield between contending fractions. ${ }^{55} \mathrm{~A}$ breaking point in internal dissentions was reached after catastrophic failure of so called the

from other counties, for example the CPC County Banská Bystrica announced insufficient work of cells, because "Members of cells are not reorganized seriously". SA Košice, f. PD K, b. 8, no. 55088/27. Komunistická mládež - prehl'ad činnosti v ČSR. (Communist youth overview of activity.)

${ }^{52}$ SA Košice, f. CK, b. 180, no. 7093/26 adm. rev. Komunistická mládež - tlačová agitácia smernice. (Communist youth - press agitation - instructions.)

${ }^{53}$ LENIN, Vladimir I. Mládeži. Bratislava : Smena, 1975, p. 242.

${ }^{54}$ A collective of Slovak historians blamed failure of process of reconstruction on formal acceptance without real interest to make it successful: "Significant and demanding instructions in sphere of organization reconstruction from local streets and country side cells to factories were accepted without resistance and objections... But it was clear that realization of reconstruction will struggle with considerable technical obstacles and, at the same time, will attract attention of state authorities and employers. Though objections were silenced (...) reconstruction was proceeding only gradually and failed to achieve originally planned extend." PLEVZA, V. et al. Prehl'ad dejín KSČ na Slovensku, p. 160.

${ }^{55} \mathrm{~F}$. I. Firsov wrote, that, "Process of ideological and organizational development of CPC during second half of 1920 significantly slowed... Social reformist parties in environment of temporary stabilization of capitalism masterly exploited conjuncture and were able to deepen 
Propaganda in political strategy of the Czechoslovakian Communist Party ...

Red Day, which was intendent to be a monumental celebration of communist holiday and proof of popularity and strength of CPC in the Republic. ${ }^{56}$ However, despite strenuous preparations, the Red Day ended as embarrassing failure. Only a mere fraction of the Communist Party members participated on manifestation. ${ }^{57}$ Non-communist press, not hiding satisfaction, informed about collapse of the Red Day. ${ }^{58}$

In July 1928, during session the Central Committee of CPC ${ }^{59}$, it was concluded, that from failure of the Red Day "the Party must above all draw lesson that it is necessary to activate the whole party apparatus, remove all shortcomings and mistakes in regard to working methods via activation of cells and with even more strenuous work accomplish process of bolshevization." 60

In Slovakia, repercussions of the Red Day fiasco were echoed primarily among young members of the Communist Party. On August 17, 1928 the Secretariat of Youth in Bratislava issued a circular letter in which expressed stance to crisis in CPC and to the Red Day. ${ }^{61}$

their influence in masses. In CPC, where after the Forth Congress (March 1927) gained a leading position fraction led by Jílek and Bolen, were increasingly emerging opportunistic mistakes. Issues of bolshevization were approached only formally. CPC was gradually losing its fighting ability”. FIRSOV, Fridrich I. Pomoc Kominterny při bolševizaci KSČ. Praha : Nakladatelství svoboda, 1988, p. 108.

56 The Department of Agitation (Agitprop) on May 25, 1928 issued a circular letter instructing county secretariats to realize all necessary preparations for celebration of the Red Day. Celebrations, set for July, $5-6$, were to be held in all counties in CSR. The most imposing commemoration were planned at Prague. It was decided to transfer as many participants as possible from localities outside of capital. Party publications should spend maximal effort to propagate the Red Day. Intention was to "convince broad strata of non-communist population about significance of the Red Day and gain them for participation on celebration." SA Košice, f. CK, b. 250 , no. $29.138 / 28$ prez. A circular letter no. 27 , issued by the Agitprop on May 25, 1928.

57 „Defeat of the Red Day, that is, a total failure of action, inevitably provoked already a longer time unnerved the left fraction to express its view about situation in the Party. "PLEVZA, V. et al. Prehl'ad dejín KSČ, p. 161.

58 Robotnícke noviny. July 14, 1928, Year XXVI, no. 158, p. 1. Likvidácia komunistickej strany. I výkonný výbor priznáva blamáž s Rudým dňom. (Liquidation of the Communist Party. Also the Executive Commission is admitting embarrassment of the Red Day.); Slovák. July 27, 1928, Year X, no. 167, Úpadok komunistov, (Decay of Communists.), p. 1.

59 The session was attended, among others, by Haken, Bolen, Jílek, Slánsky, Zápotocký and Gottwald.

${ }^{60}$ KRÁL, Václav. Cesta k leninizmu. Prameny k dějinám KSČ v letech 1921 - 1929. Praha : Academia, 1971, p. 301.

${ }^{61}$ According to the Secretariat „Young workers are in whole state working for rescue CPC and all its endeavor leads to bear out our Party from this heavy crisis and to purify the Party from social democratic and Trockyst elements, which are still remaining in our Party." State Archive Banská Bystrica, b. Rimavská Sobota, f. Okresný úrad Šafárikovo, b. 3. Komunistická strana v Bratislave, rozpory medzi členstvom. (The Communist Party in Bratislava contradictions among members.) 
As several times before, the Marx-Leninist fraction in CPC got help from the Communist International, which proved to be of decisive importance. With unconditional support CI, during the Fifth Congress of CPC (18 - 23 February 1929), Klement Gotwald was elected chairman of the Central Committee of CPC. Persons opposing strict Marx-Leninist line were expulsed from the Party. ${ }^{62}$ Under K. Gottwald's chairmanship, the Communist Party of Czechoslovakia was a loyal member of the Communist International during remaining years of CSR.

\section{Zhrnutie}

\section{Propaganda v politickej stratégii Komunistickej strany Českosloven- ska v prvej dekáde medzivojnovej Československej republiky}

Životným záujmom Komunistickej strany Československa (KSČ) v boji o získanie politickej moci bolo zatraktívnit’ jej program pre široké masy československého obyvatel'stva. Marx-leninizmus, ktorý sa stal ideologickou základňou KSČ, sa prezentoval ako jediná relevantná ideológia schopná nastolit' „sociálne spravodlivú“ spoločnost'. Revolúcia ako cesta komunistického režimu k nastoleniu vlády bola prezentovaná ako nevyhnutná, pretože bola v súlade so zákonmi spoločenského pokroku, ktoré formulovali Fridrich Engels, Karol Marx a Vladimír I. Lenin. Podstatnú úlohu v šírení ideológie marxleninizmu mala podl'a vedenia KSČ propaganda. Napriek striktne formulovaným princípom marx-leninskej ideológie sa komunistická propaganda počas existencie Československa menila v závislosti od meniaceho sa politického vývoja. V predloženom príspevku sú sledované peripetie formy a obsahu komunistickej propagandy v sledovanom období. Dôraz je kladený na doteraz nepublikované archívne dokumenty, uložené v slovenských a českých archívoch. Neocenitel'ným zdrojom, ktorý ponúka pohl'ad na konkrétne fungovanie komunistickej propagandy, je súčasná tlač, predovšetkým periodiká Pravda Chudoby a Pravda, ktoré reprezentovali ideologické názory Komunistickej strany Československa. Relevantným zdrojom informácií sú sociálnodemokratické Robotnícke noviny, ktoré pozorne sledovali vývoj svojho hlavného rivala KSČ.

\footnotetext{
${ }^{62}$ In words of F. I. Firsov, „Ferocious fight, which the Marx-Leninist Forces led by K. Gottwald waged against opportunism for consolidation of the Party on revolutionary platform culminated at Fifth Congress of CPC, which was held during 18 - 23 of February 1929. The Fifth became a decisive landmark in fight for overcoming a intra Party into an organization of Leninist type... This process progressed with direct support and help of leading authority of international communist movement - executive of the Communist International..." FIRSOV, F. I. Pomoc kominterny, p. 114 - 115.
} 